Article

\title{
Photoreactions of Endohedral Metallofullerene with Siliranes: Electronic Properties of Carbosilylated $\mathrm{Lu}_{3} \mathrm{~N} @ \mathrm{I}_{h}-\mathrm{C}_{80}{ }^{\dagger}$
}

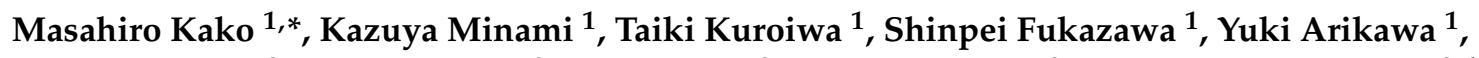 \\ Michio Yamada ${ }^{2}$, Yutaka Maeda ${ }^{2}$, Qiao-Zhi Li ${ }^{3}$, Shigeru Nagase ${ }^{3, *}$ and Takeshi Akasaka ${ }^{2,4,5,6, *}$ \\ 1 Department of Engineering Science, The University of Electro-Communications, Chofu 182-8585, Japan; \\ minami@chemk.pc.uec.ac.jp (K.M.); kuroiwa@chemk.pc.uec.ac.jp (T.K.); fukazawa@chemk.pc.uec.ac.jp (S.F.); \\ arikawa@chemk.pc.uec.ac.jp (Y.A.) \\ 2 Department of Chemistry, Tokyo Gakugei University, Tokyo 184-8501, Japan; \\ myamada@u-gakugei.ac.jp (M.Y.); ymaeda@u-gakugei.ac.jp (Y.M.) \\ 3 Fukui Institute for Fundamental Chemistry, Kyoto University, Kyoto 606-8103, Japan; \\ lqz1153672945@stu.xjtu.edu.cn \\ 4 Life Science Center of Tsukuba Advanced Research Alliance, University of Tsukuba, Ibaraki 305-8577, Japan \\ 5 Foundation for Advancement of International Science, Ibaraki 305-0821, Japan \\ 6 School of Materials Science and Engineering, Huazhong University of Science and Technology, \\ Wuhan 430074, China \\ * $\quad$ Correspondence: kako@e-one.uec.ac.jp (M.K.); nagase@ims.ac.jp (S.N.); akasaka@tara.tsukuba.ac.jp (T.A.); \\ Tel.: +81-42-443-5570 (M.K.); Fax: +81-42-443-5563 (M.K.) \\ + Dedicated to Professor Marian Mikołajczyk on the occasion of his 80th birthday.
}

Academic Editor: Shunichi Fukuzumi

Received: 29 April 2017; Accepted: 17 May 2017; Published: 20 May 2017

\begin{abstract}
Photochemical carbosilylation of $\mathrm{Lu}_{3} \mathrm{~N} @ I_{h}-\mathrm{C}_{80}$ was performed using siliranes (silacyclopropanes) to afford the corresponding [5,6]- and [6,6]-adducts. Electrochemical studies indicated that the redox potentials of the carbosilylated derivatives were shifted cathodically in comparison with those of the [5,6]-pyrrolidino adducts. The electronic effect of the silirane addends on $\mathrm{Lu}_{3} \mathrm{~N} @ I_{h}-\mathrm{C}_{80}$ was verified on the basis of density functional theory calculations.
\end{abstract}

Keywords: endohedral metallofullerene; $\mathrm{Lu}_{3} \mathrm{~N} @ I_{h}-\mathrm{C}_{80}$; carbosilylation; silirane; redox property

\section{Introduction}

Endohedral metallofullerenes (EMFs) [1-12] have attracted much interest because of their fascinating structural and electronic properties. On the basis of the encapsulated metals, the properties and reactivities of EMFs are significantly different from those of empty fullerenes. For the last few decades, trimetallic nitride template endohedral metallofullerenes (TNT EMFs), $\mathrm{M}_{3} \mathrm{~N} @ I_{h}-\mathrm{C}_{80}(\mathrm{M}=\mathrm{Sc}$, $\mathrm{Lu}, \mathrm{Y}$, and $\mathrm{Gd}$ ), have been extensively studied as representatives of cluster fullerenes, for which potential applications have been explored in the fields of molecular electronics, nanomaterials, and biochemistry [1-14]. For example, $\mathrm{Lu}_{3} \mathrm{~N} @ I_{h}-\mathrm{C}_{80}$ is an attractive compound from a practical viewpoint. The reduction potential of $\mathrm{Lu}_{3} \mathrm{~N} @ I_{h}-\mathrm{C}_{80}$ is lower than those of the other trimetallic nitride template (TNT) EMFs, $\mathrm{M}_{3} \mathrm{~N} @ I_{h}-\mathrm{C}_{80}\left(\mathrm{M}=\mathrm{Sc}, \mathrm{Y}\right.$, etc.), $\mathrm{C}_{60}$, and $\mathrm{C}_{70}$. This property of $\mathrm{Lu}_{3} \mathrm{~N} @ I_{h}-\mathrm{C}_{80}$ is expected to be advantageous with respect to its use as an acceptor in organic photovoltaic (OPV) devices. Previously, OPV devices using some $\mathrm{Lu}_{3} \mathrm{~N}_{I_{h}}-\mathrm{C}_{80}$ derivatives with lower reduction potentials were reported to show higher power conversion efficiency than that of $\mathrm{C}_{60}$-based analogous devices [15-17].

Meanwhile, the exohedral functionalization of EMFs has been studied extensively as an effective method for modifying the properties of EMFs for many applications [1-12]. As a part of our 
study of the chemical derivatization of EMFs, we reported the addition reactions of $\mathrm{Lu}_{3} \mathrm{~N} @ I_{h}-\mathrm{C}_{80}$ with disilirane, silylene, and digermirane to afford the corresponding silylated and germylated adducts [18-20]. The redox potentials of these derivatives were shifted cathodically relative to that of pristine $\mathrm{Lu}_{3} \mathrm{~N} @ I_{h}-\mathrm{C}_{80}$, as expected from the electron-donating effect of silyl and germyl groups. These results prompted us to apply alternative silylation methods to $\mathrm{Lu}_{3} \mathrm{~N} @ I_{h}-\mathrm{C}_{80}$, which will enable fine-tuning of its electronic properties. More recently, we reported the photochemical addition of $\mathrm{Sc}_{3} \mathrm{~N} @ I_{h}-\mathrm{C}_{80}$ and silirane (silacyclopropane) $\mathbf{1}$ to afford three isomeric carbosilylated derivatives of $\mathrm{Sc}_{3} \mathrm{~N} @ I_{h}-\mathrm{C}_{80}$ [21]. Spectroscopic measurements indicated that the addition of $\mathbf{1}$ occurred at the $[5,6]$ (a pentagon and a hexagon), and the [6,6] (two hexagons) ring junctions. In addition, the oxidation potentials of the carbosilylated adducts were shifted moderately compared to that of pristine $\mathrm{Sc}_{3} \mathrm{~N} @ I_{h}-\mathrm{C}_{80}$. Herein, we report the carbosilylation of $\mathrm{Lu}_{3} \mathrm{~N} @ I_{h}-\mathrm{C}_{80}$ via photoreactions using siliranes 1 [21] and 2 [22] to afford the corresponding [5,6]- and [6,6]-adducts. The electronic effect of silirane addition on $\mathrm{Lu}_{3} \mathrm{~N} @ I_{h}-\mathrm{C}_{80}$ is discussed in comparison with that of the 1,3-dipolar addition of azomethine ylides [23,24].

\section{Results and Discussion}

\subsection{Preparation and Structural Analysis of the Carbosilylated Derivatives of $L u_{3} N @ I_{h}-C_{80}$}

A toluene solution of $\mathrm{Lu}_{3} \mathrm{~N} @ I_{h}-\mathrm{C}_{80}$ and 1 was photo-irradiated using two $500 \mathrm{~W}$ halogen lamps (cutoff $<400 \mathrm{~nm}$ ) (Scheme 1). After photolysis for $60 \mathrm{~h}$, preparative high performance liquid chromatography (HPLC) of the reaction mixture was performed to separate three compounds $\mathbf{3} \mathbf{a}, \mathbf{3} \mathbf{b}$, and 3c (Figures S1 and S2, in the Supporting Information). Matrix-assisted laser desorption ionization time-of-flight (MALDI-TOF) mass spectrometry of $\mathbf{3 a}, \mathbf{3} \mathbf{b}$, and $\mathbf{3} \mathbf{c}$ exhibited molecular ion peaks at $\mathrm{m} / \mathrm{z}$ $2009\left(\mathrm{M}^{-}\right)$, as expected for 1:1 adducts of $\mathrm{Lu}_{3} \mathrm{~N} @ I_{h}-\mathrm{C}_{80}$ and $\mathbf{1}$ (Figure S3). The spectra also show base peaks at $m / z 1499$ for the fragment ion $\mathrm{Lu}_{3} \mathrm{~N} @ I_{h}-\mathrm{C}_{80}{ }^{-}$. Similarly, photoreaction of $\mathrm{Lu}_{3} \mathrm{~N} @ I_{h}-\mathrm{C}_{80}$ and 2 provided three isomeric adducts $4 \mathbf{a}, \mathbf{4 b}$, and $4 \mathbf{c}$. The yields of $\mathbf{3 a}, \mathbf{3 b}, \mathbf{4 a}$, and $4 \mathbf{b}$ were calculated to be $30 \%, 7 \%, 26 \%$ and $16 \%$, respectively, whereas those of $3 \mathrm{c}$ and $4 \mathrm{c}$ were not determined because they contained inseparable impurities.

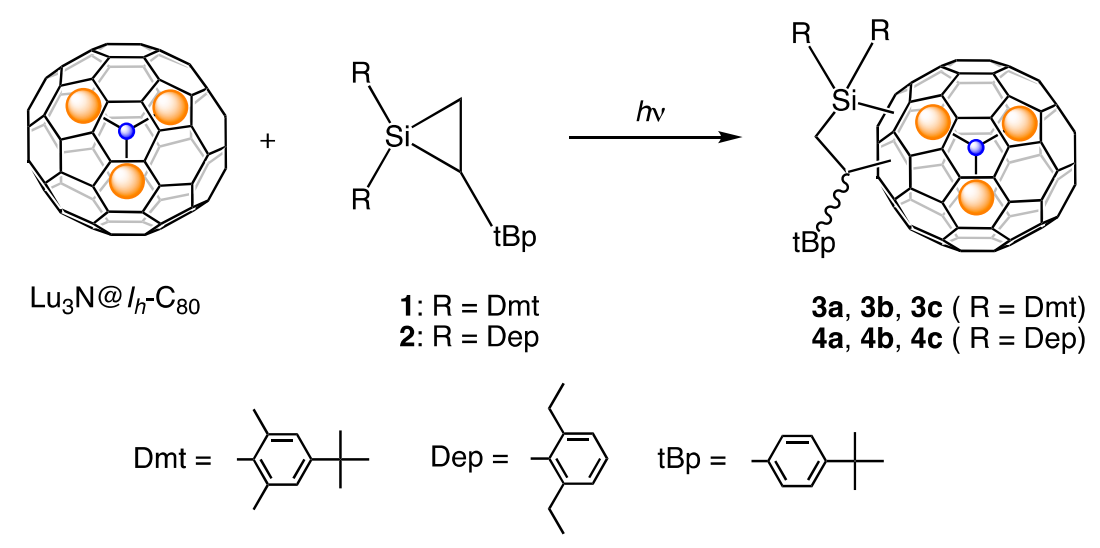

Scheme 1. Photoreactions of $\mathrm{Lu}_{3} \mathrm{~N} @ I_{h}-\mathrm{C}_{80}$ with siliranes $\mathbf{1}$ and 2.

Assuming 1,2-addition of $\mathbf{1}$ and $\mathbf{2}$ to $\mathrm{Lu}_{3} \mathrm{~N} @ I_{h}-\mathrm{C}_{80}$, four structures $\mathbf{A}-\mathbf{D}$ are possible for the addition sites (Figure 1). To obtain an insight into their addition patterns, visible-near-infrared (vis-NIR) spectroscopy was conducted for the adducts (Figure 2). Previous studies indicate that the vis-NIR spectra of the [5,6]- and [6,6]-pyrrolidino derivatives of $\mathrm{Lu}_{3} \mathrm{~N} @ I_{h}-\mathrm{C}_{80}$ exhibit absorption maxima at approximately 870 and $820 \mathrm{~nm}$, respectively [24,25]. The vis-NIR spectra of $\mathbf{3 a}, \mathbf{3} \mathbf{b}, \mathbf{4 a}$, and $4 \mathrm{~b}$ show absorption maxima around $880 \mathrm{~nm}$, which are similar to those of the [5,6]-pyrrolidino derivatives [24,25] (Figure 2). Meanwhile, the vis-NIR spectra of $3 \mathbf{c}$ and $4 \mathbf{c}$ show broad absorption maxima at 811 and $803 \mathrm{~nm}$, which resemble those of the [6,6]-pyrrolidino derivatives [24,25]. Therefore, 
$\mathbf{3 a}, \mathbf{3 b}, \mathbf{4 a}$, and $\mathbf{4 b}$ are assignable to the [5,6]-adducts $\mathbf{A}$ and $\mathbf{B}$. On the other hand, $\mathbf{3} \mathbf{c}$ and $\mathbf{4 c}$ are probably the $[6,6]$-adducts $\mathbf{C}$ and/or $\mathbf{D}$ (See also Figure 3).

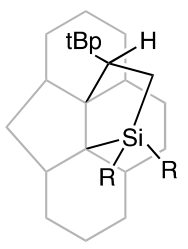

A

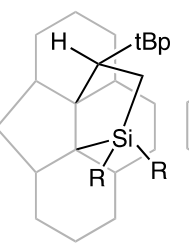

B

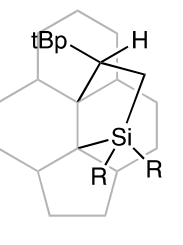

C

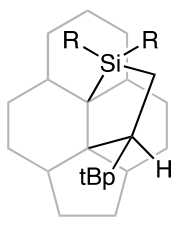

D

$[5,6]$-adduct

$[6,6]$-adduct

Figure 1. Possible addition patterns of 1,2-adducts derived from $\mathrm{Lu}_{3} \mathrm{~N} @ I_{h}-\mathrm{C}_{80}$ and siliranes.

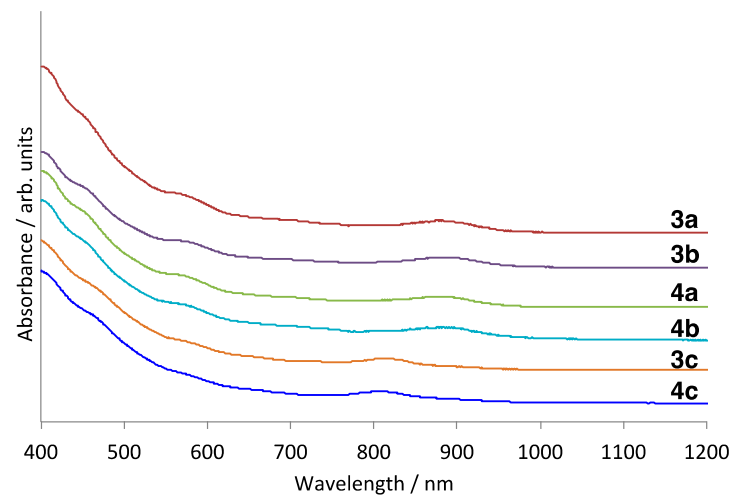

Figure 2. Vis-NIR absorption spectra of $3 \mathbf{a}-\mathbf{c}$ and $4 a-c$ in $\mathrm{CS}_{2}$.



3a, 3b: $R=D m t$

4a, $\mathbf{4 b}: \mathrm{R}=\mathrm{Dep}$

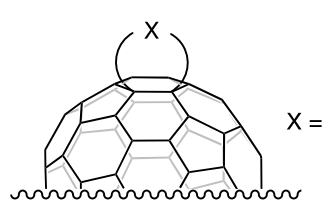

3c: $R=D m t$

4c: $R=$ Dep

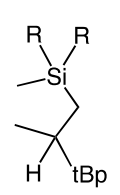

Bp

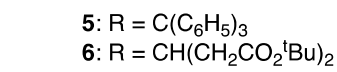

Figure 3. Partial structures of the $\mathrm{Lu}_{3} \mathrm{~N} @ I_{h}-\mathrm{C}_{80}$ derivatives.

In the ${ }^{1} \mathrm{H}-\mathrm{NMR}$ spectrum of $\mathbf{3 a}$, signals for four methyl groups and three tert-butyl groups, as well as aromatic protons were observed (Figure S5). The ring protons of the silacyclopentane addend of 3a constitute an ABX spin system at 3.66, 2.85, and 1.84 ppm as double doublets. Meanwhile, the ${ }^{13} \mathrm{C}$-NMR spectrum of $3 \mathrm{a}$ exhibited 86 quaternary and six tertiary $\mathrm{sp}^{2}$ carbon signals, as well as two $\mathrm{sp}^{3}$ carbon signals of the $I_{h}-\mathrm{C}_{80}$ cage (Figure S7). The carbon signals of the methylene and methine of the silacyclopentane ring, the three tert-butyl and four methyl groups were also shown in the spectrum. These spectral data are consistent with the structure of $3 \mathbf{a}$ as the [5,6]-adduct with $C_{1}$ symmetry. The ${ }^{1} \mathrm{H}-\mathrm{NMR}$ spectrum of $\mathbf{3} \mathbf{b}$ is very similar to that of $\mathbf{3 a}$ (Figure $\mathrm{S6}$ ). On the basis of the vis-NIR and ${ }^{1} \mathrm{H}-\mathrm{NMR}$ spectra, $\mathbf{3 a}$ and $\mathbf{3} \mathbf{b}$ were determined to be a pair of diastereomers $\mathbf{A}$ and $\mathbf{B}$, although the absolute configurations of 4-tert-butylphenyl (denoted as $\mathrm{tBp}$ ) groups remain unknown.

The ${ }^{13} \mathrm{C}$-NMR spectrum of $\mathbf{4 a}$, the main product obtained from $\mathbf{2}$, is similar to that of $\mathbf{3 a}$, showing $86 \mathrm{sp}^{2}$ carbon atom signals (Figure S10). The carbon signals of the silirane addend and two $\mathrm{sp}^{3}$ carbon signals of the $I_{h}-C_{80}$ cage were also observed. The ${ }^{1} \mathrm{H}-\mathrm{NMR}$ spectra of $\mathbf{4 a}$ and $\mathbf{4} \mathbf{b}$ also indicate the structures of the silirane addends as for the case of $\mathbf{3 a}$ and $\mathbf{3 b}$ (Figures S8 and S9). As shown in the vis-NIR spectra, it is suggested that $\mathbf{4 a}$ and $\mathbf{4 b}$ are a pair of diastereomers of the [5,6]-adducts. On the 
other hand, spectroscopic studies of $3 c$ and $4 c$ have hitherto been unsuccessful because of their low yields and impurities.

\subsection{Electrochemical Studies}

The electrochemical properties of $\mathbf{3 a}, \mathbf{3 b}, \mathbf{4 a}$, and $\mathbf{4 b}$ were measured using cyclic voltammetry $(\mathrm{CV})$ and differential pulse voltammetry (DPV). The redox potentials of the related compounds are summarized in Table 1. As shown in Figures S11 and S12, the oxidation of $\mathbf{3 a}, \mathbf{3 b}$, $\mathbf{4 a}$, and $4 \mathbf{b}$ resulted in the removal of the silirane addends during the electrochemical analyses, affording pristine $\mathrm{Lu}_{3} \mathrm{~N} @ I_{h}-\mathrm{C}_{80}$. The first oxidation $\left(E^{\mathrm{ox}}{ }_{1}\right)$ potentials of $\mathbf{3 a}, \mathbf{3 b}, \mathbf{4 a}$, and $\mathbf{4} \mathbf{b}$ are lower than that of $\mathrm{Lu}_{3} \mathrm{~N} @ I_{h}-\mathrm{C}_{80}$ within the range of 360-400 $\mathrm{mV}$. These remarkable cathodic shifts of the oxidation potentials are commonly observed for silylated fullerenes because of the electron-donating properties of the silyl groups [18-21]. Meanwhile, the values of the first reduction $\left(E^{\text {red }}{ }_{1}\right)$ potentials of $\mathbf{3 a}, \mathbf{3} \mathbf{b}, \mathbf{4} \mathbf{a}$, and $4 \mathbf{b}$ are close to that of $\mathrm{Lu}_{3} \mathrm{~N} @ I_{h}-\mathrm{C}_{80}$. These redox data are compared to those of 5 [23] and 6 [24] as the $[5,6]$-pyrrolidino adducts of $\mathrm{Lu}_{3} \mathrm{~N} @ I_{h}-\mathrm{C}_{80}$. The first reduction potentials of 5 and 6 are -1.13 and $-1.14 \mathrm{~V}$, respectively. According to the reported voltammograms, the $E^{\text {ox }} 1$ potentials of 5 and 6 are both about $+0.34 \mathrm{~V}$, respectively, although the exact $E^{\mathrm{ox}}{ }_{1}$ values are not given in the literature [23,24]. As a result, the redox potentials of $\mathbf{3 a}, \mathbf{3 b}, \mathbf{4 a}$, and $\mathbf{4 b}$ shift cathodically compared to those of 5 and $\mathbf{6}$. These effects of silyl functional groups are also observed for carbosilylated derivatives of $\mathrm{Sc}_{3} \mathrm{~N} @ I_{h}-\mathrm{C}_{80}$ [21].

Table 1. Redox potentials $(\mathrm{V})^{\mathrm{a}}$ of $\mathbf{3 a}, \mathbf{3} \mathbf{b}, \mathbf{4 a}, \mathbf{4} \mathbf{b}$, and related compounds.

\begin{tabular}{cccc}
\hline compound & $\boldsymbol{E}^{\mathbf{o x}} \mathbf{1}$ & $\boldsymbol{E}^{\text {red }}{ }_{\mathbf{1}}$ & $\boldsymbol{E}^{\text {red }} \mathbf{2}$ \\
\hline $\mathrm{Lu}_{3} \mathrm{~N} @ I_{h}-\mathrm{C}_{80} \mathrm{~b}$ & +0.61 & -1.39 & -1.83 \\
$\mathbf{3 a}$ & $+0.23^{\mathrm{c}}$ & -1.38 & -1.73 \\
$\mathbf{3 b}$ & $+0.25^{\mathrm{c}}$ & -1.35 & -1.71 \\
$\mathbf{4 a}$ & $+0.22^{\mathrm{c}}$ & -1.37 & -1.75 \\
$\mathbf{4 b}$ & $+0.21^{\mathrm{c}}$ & -1.41 & -1.77 \\
$\mathbf{5}^{\mathrm{d}}$ & & -1.13 & -1.64 \\
$\mathbf{6}^{\mathrm{e}}$ & & -1.14 & \\
\hline
\end{tabular}

a Values obtained by DPV are in volts relative to the ferrocene/ferrocenium couple. ${ }^{\mathrm{b}}$ Data from ref. [18]. ${ }^{\mathrm{c}}$ Irreversible. ${ }^{d}$ Data from ref. [23]. ${ }^{\mathrm{e}}$ Data from ref. [24].

The $E^{\text {red }} 1$ potentials of $\mathbf{3 a}, \mathbf{3 b}, \mathbf{4 a}$, and $\mathbf{4 b}$ are interesting from the viewpoints of $\mathrm{Lu}_{3} \mathrm{~N} @ I_{h}-\mathrm{C}_{80}-\mathrm{based}$ OPV acceptors, for which optimization of the lowest unoccupied molecular orbital (LUMO) levels is an important factor in improving the open circuit voltages of the corresponding solar cells [15,16]. The $E^{\text {red }} 1$ potentials of the [5,6]-pyrrolidino adducts 5 [23] and 6 [24] are shifted positively relative to that of $\mathrm{Lu}_{3} \mathrm{~N} @ I_{h}-\mathrm{C}_{80}$. In contrast, 3a, 3b, $4 \mathbf{a}$, and $4 \mathbf{b}$ maintain the low reduction potential of pristine $\mathrm{Lu}_{3} \mathrm{~N} @ I_{h}-\mathrm{C}_{80}$. Although the functions of $\mathbf{3 a}, \mathbf{3 b}, \mathbf{4} \mathbf{a}$, and $4 \mathbf{b}$ as OPV acceptors are unknown, carbosilylation would be an effective method to adjust the electronic properties of fullerenes for electronic functional materials.

\subsection{Theoretical Calculations}

To obtain an insight into the structural and electronic properties of $\mathbf{3 a}, \mathbf{3 b}, \mathbf{4 a}$, and $\mathbf{4 b}$, isomers of [5,6]-carbosilylated $\mathrm{Lu}_{3} \mathrm{~N} @ I_{h}-\mathrm{C}_{80}$ were calculated by the density functional theory using the B3LYP method [26-28]. The partial structures of the calculated molecules are shown in Figure 4 with the relative energies. The optimized structures of these molecules are also shown in Figures S13-S16. These structures were calculated with a few different orientations of the $\mathrm{Lu}_{3} \mathrm{~N}$ cluster. As for the configurations of the silirane addend, 3A-I, 3A-II, 3A-III, 4A-I, 4A-II, and 4A-III are calculated molecules for the diastereomer A in Figure 1, while 3B-I, 3B-II, 3B-III, 4B-I, 4B-II, and 4B-III correspond to B. These structures are grouped into four configurations: (3A-I, 3A-II, 3A-III); (3B-I, 3B-II, 3B-III); (4A-I, 4A-II, 4A-III); and (4B-I, 4B-II, 4B-III). Each of the structural groups has three orientations of the 
$\mathrm{Lu}_{3} \mathrm{~N}$ cluster, as shown in Figure 4. As expected, the relative energies of the adducts vary depending on the orientations of the $\mathrm{Lu}_{3} \mathrm{~N}$ cluster and the configurations of the silirane addends. Among these isomers, 3A-I, 4A-I, 3B-I, and 4B-I, in which the Y-shaped $\mathrm{Lu}_{3} \mathrm{~N}$ clusters straddle the addition sites, have relatively lower energies. These calculations indicate that the orientations of the $\mathrm{Lu}_{3} \mathrm{~N}$ clusters in $3 \mathbf{a}, 3 \mathbf{b}, \mathbf{4 a}$, and $4 \mathbf{b}$ should be somewhat restricted. As a result, we regard 3A-I, 3B-I, 4A-I, and 4B-I as the most preferable optimized structures for $\mathbf{3 a}, \mathbf{3 b}, \mathbf{4 a}$, and $\mathbf{4 b}$, although the absolute configurations of the $\mathrm{tBp}$ groups remain unclear.

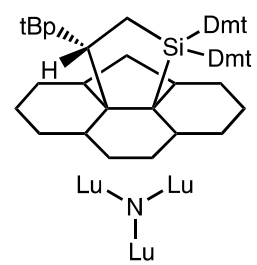

3A-I $(0.00)$

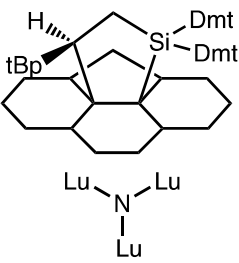

3B-I (0.49)

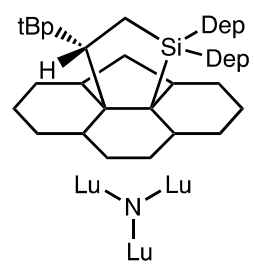

4A-I $(0.00)$

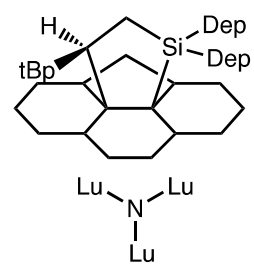

4B-I (0.69)



3A-II (2.12)

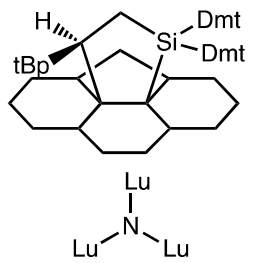

3B-II (3.07)

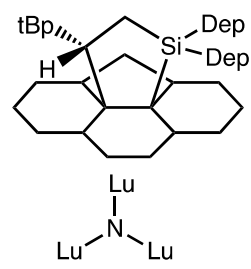

4A-II (1.76)

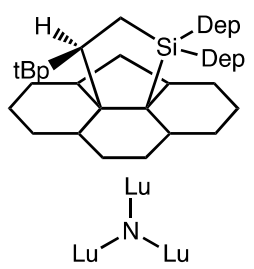

4B-II (3.22)

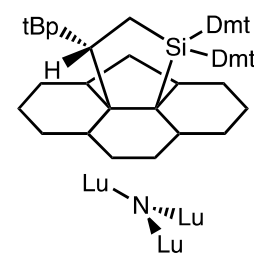

3A-III (3.27)



3B-III (11.28)

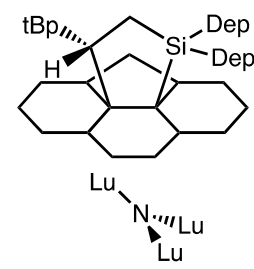

4A-III (3.52)

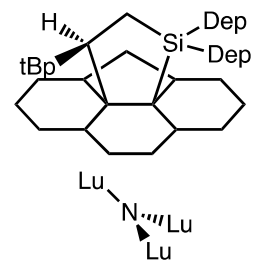

4B-III (4.47)

Figure 4. Representation of the configurations of silirane addends and the orientations of the $\mathrm{Lu}_{3} \mathrm{~N}$ cluster in the optimized structures. Values in the parentheses are the relative energies in $\mathrm{kcal} / \mathrm{mol}$. The values of 3A-II, 3A-III, 3B-I, 3B-II, and 3B-III are relative to that of 3A-I. For 4A-II, 4A-III, 4B-I, 4B-II, and $4 \mathrm{~B}-\mathrm{III}$, the values are relative to that of $4 \mathrm{~A}-\mathrm{I}$.

In addition, the redox properties of carbosilylated $\mathrm{Lu}_{3} \mathrm{~N} @ I_{h}-\mathrm{C}_{80}$ are consistent with the calculated energies of the highest occupied molecular orbital (HOMO) and LUMO levels of the optimized structures. As shown in Table 2, the HOMOs of 3A-I, 3B-I, 4A-I, and 4B-I are higher within the range of 0.45-0.53 eV compared with that of pristine $\mathrm{Lu}_{3} \mathrm{~N} @ I_{h}-\mathrm{C}_{80}$. In contrast, the LUMO energies of 3A-I, 3B-I, $4 \mathrm{~A}-\mathrm{I}$, and $4 \mathrm{~B}-\mathrm{I}$ are almost the same as that of pristine $\mathrm{Lu}_{3} \mathrm{~N} @ I_{h}-\mathrm{C}_{80}$. These results are fully consistent 
with the experimental redox properties of $\mathbf{3 a}, \mathbf{3 b}, \mathbf{4 a}$, and $\mathbf{4 b}$. Therefore, the carbosilylated structures were verified given the electron-donating properties of the silyl groups.

Table 2. Calculated HOMO/LUMO levels (eV) of $\mathrm{Lu}_{3} \mathrm{~N} @ I_{h}-\mathrm{C}_{80}, 3 \mathrm{~A}-\mathrm{I}, 3 \mathrm{~B}-\mathrm{I}, 4 \mathrm{~A}-\mathrm{I}$, and 4B-I.

\begin{tabular}{ccc}
\hline compound & HOMO & LUMO \\
\hline $\mathrm{Lu}_{3} \mathrm{~N} @ \mathrm{I}_{h}-\mathrm{C}_{80}$ & -5.47 & -2.90 \\
3A-I & -4.98 & -2.90 \\
3B-I & -4.99 & -2.91 \\
$4 \mathrm{~A}-\mathrm{I}$ & -5.01 & -2.92 \\
4B-I & -5.02 & -2.95 \\
\hline
\end{tabular}

\section{Materials and Methods}

\subsection{General}

All chemicals were reagent grade, purchased from Wako Pure Chemical Industries Ltd (Osaka, Japan). $\mathrm{Lu}_{3} \mathrm{~N} @ I_{h}-\mathrm{C}_{80}$ was purchased from Luna Innovations Inc. (Danville, CA, USA). 1,2-dichlorobenzene (ODCB) was distilled from $\mathrm{P}_{2} \mathrm{O}_{5}$ under vacuum before use. Toluene was distilled from benzophenone sodium ketyl under dry $\mathrm{N}_{2}$ prior to use. Reagents were used as purchased unless otherwise specified. HPLC was performed on an LC-908 apparatus (Japan Analytical Industry Co. Ltd., Tokyo, Japan) monitored using a UV3702 detector. Analytical HPLC was performed on a PU-1586 pump with a UV-1575 detector (JASCO Corp., Tokyo, Japan). Buckyprep (i.d. $20 \mathrm{~mm} \times 250 \mathrm{~mm}, 4.6 \mathrm{~mm} \times 250 \mathrm{~mm}$ ), Buckyprep-M (i.d. $10 \mathrm{~mm} \times 250 \mathrm{~mm}, 4.6 \mathrm{~mm} \times 250 \mathrm{~mm}$ ), and 5PBB (i.d. $10 \mathrm{~mm} \times 250 \mathrm{~mm}, 4.6 \mathrm{~mm} \times 250 \mathrm{~mm}$ ) columns (Nacalai Tesque Inc., Kyoto, Japan) were used for HPLC separation. Toluene was used as the eluent for HPLC. The ${ }^{1} \mathrm{H}$ and ${ }^{13}$ C-NMR measurements were conducted on a JEOL ECA-500 spectrometer (JEOL Ltd., Tokyo, Japan). MALDI-TOF mass experiments were performed (Autoflex III Smartbeam, Bruker Daltonics, Billerica, MA, USA) with 1,1,4,4-tetraphenyl-1,3-butadiene (TPB) as the matrix in both positive and negative ion modes. Absorption spectra were measured using a UV spectrophotometer (UV-3150, Shimadzu Corp., Kyoto, Japan). Cyclic voltammograms and differential pulse voltammograms were recorded on an electrochemical analyzer (BAS CV50W, BAS Inc., Tokyo, Japan). The reference electrode was a saturated calomel reference electrode (SCE). The glassy carbon electrode was used as the working electrode, and a platinum wire was used as the counter electrode. All potentials are referenced to the ferrocene/ferrocenium couple $\left(\mathrm{Fc} / \mathrm{Fc}^{+}\right)$as the standard. $(n-\mathrm{Bu})_{4} \mathrm{NPF}_{6}(0.1 \mathrm{M})$ in ODCB was used as the supporting electrolyte solution.

\subsection{Photoreaction of $\mathrm{Lu}_{3} N @ \mathrm{I}_{h}-C_{80}$ with $\mathbf{1}$}

A Pyrex tube (7 mm i.d.) containing $\mathrm{Lu}_{3} \mathrm{~N} @ I_{h}-\mathrm{C}_{80}\left(0.7 \mathrm{mg}, 4.7 \times 10^{-4} \mathrm{mmol}\right), 1(11.5 \mathrm{mg}$, $\left.2.3 \times 10^{-2} \mathrm{mmol}\right)$, and toluene $(3.0 \mathrm{~mL})$ was prepared and degassed using freeze-pump-thaw cycles under reduced pressure. Subsequently, the solution was irradiated for $60 \mathrm{~h}$ with a $500 \mathrm{~W}$ halogen lamp using an aqueous sodium nitrite filter solution (cutoff $<400 \mathrm{~nm}$ ) under an argon atmosphere. The resulting reaction mixtures were separated using preparative HPLC with Buckyprep-M, Buckyprep, and 5PBB columns to isolate $\mathbf{3 a}, \mathbf{3 b}$, and $\mathbf{3 c}$.

3a: ${ }^{1} \mathrm{H}-\mathrm{NMR}\left(\mathrm{CD}_{2} \mathrm{Cl}_{2}\right)$ $\delta$ 7.49-7.32 (m, 4H), $7.28(\mathrm{~s}, 1 \mathrm{H}), 7.04(\mathrm{~s}, 1 \mathrm{H}), 7.02(\mathrm{~s}, 1 \mathrm{H}), 6.95(\mathrm{~s}, 1 \mathrm{H}), 3.66$ $(\mathrm{dd}, 1 \mathrm{H}, J=2.5 \mathrm{~Hz}, 15.0 \mathrm{~Hz}), 3.00(\mathrm{~s}, 3 \mathrm{H}), 2.85(\mathrm{dd}, 1 \mathrm{H}, J=13.5 \mathrm{~Hz}, 15.0 \mathrm{~Hz}), 2.73(\mathrm{~s}, 3 \mathrm{H}), 2.43$ $(\mathrm{s}, 3 \mathrm{H}), 2.11(\mathrm{~s}, 3 \mathrm{H}), 1.84(\mathrm{dd}, 1 \mathrm{H}, J=2.5 \mathrm{~Hz}, 13.5 \mathrm{~Hz}), 1.40(\mathrm{~s}, 9 \mathrm{H}), 1.31(\mathrm{~s}, 9 \mathrm{H}), 1.23(\mathrm{~s}, 9 \mathrm{H}) ;{ }^{13} \mathrm{C}-\mathrm{NMR}$ $\left(\mathrm{CDCl}_{3}: \mathrm{CS}_{2}=1: 1\right) \delta 156.88(1 \mathrm{C}), 156.79$ (1C), $155.84(1 \mathrm{C}), 155.47$ (1C), 153.73 (1C), 153.24 (1C), 153.11 (1C), $152.31(1 \mathrm{C}), 151.08(1 \mathrm{C}), 150.93$ (1C), 148.85 (1C), 148.65 (1C), $148.34(1 \mathrm{C}), 147.88$ (1C), 147.56 (1C), 147.22 (2C), 146,66 (1C), 146.38 (1C), 144.88 (1C), $144.64(1 \mathrm{C}), 144.34(1 \mathrm{C}), 144.29$ (1C), 144.20 (1C), $144.01(1 \mathrm{C}), 143.57(1 \mathrm{C}), 142.97$ (1C), 142.58 (1C), 142.35 (1C), 142.32 (1C), $142.26(1 \mathrm{C}), 142.13$ (2C), 
142.06(1C), 141.90 (1C), 141.78 (1C), 141.64 (2C), 141.38 (1C), 141.03 (1C), 140.73 (2C), 140.59 (2C), 140.54 (1C), 140.28 (1C), 139.69 (1C), 139.53 (1C), 139.13 (1C), 138.95 (1C), 138.71 (1C), 138.68 (1C), 138.43 (1C), 138.20 (1C), 137.78 (1C), 137.71 (1C), 137.20 (1C), 137.11 (1C), 137.00 (1C), 136.82 (1C), 136.68 (1C), 136.37 (2C), 136.23 (1C), 136.15 (2C), 135.30 (1C), 135.24 (1C), 135.08 (1C), 135.04 (1C), 134.78 (1C), 134.57 (1C), 134.25 (1C), 134.07 (1C), 133.33 (1C), 132.27 (1C), 131.24 (1C), 130.39 (1C), 129.75 (1C), 129.70 (1C), 129.61 (1C), 126.85 (1C), 126.33 (1C), 126.07 (1C), 125.19 (1C), 124.98 (4C), 118.55 (1C), 109.94 (1C), 108.55 (1C), 103.31 (1C), 63.46 (1C), 59.36 (1C), 54.07 (1C), 34.62 (1C), 34.57 (1C), 34.23 (1C), 31.62 (3C), 31.46 (3C), 31.24 (3C), 30.13 (1C), 26.74 (1C), 26.05 (1C), 23.87 (1C), 20.70 (1C); vis-NIR (CS $)$ $\lambda_{\max } 874 \mathrm{~nm}$; MALDI-TOF MS m/z $2009\left(M^{-}\right), 1499\left(\mathrm{Lu}_{3} \mathrm{~N}_{\mathrm{I}_{h}} \mathrm{C}_{80}{ }^{-}\right)$.

3b: ${ }^{1} \mathrm{H}-\mathrm{NMR}\left(\mathrm{CD}_{2} \mathrm{Cl}_{2}: \mathrm{CS}_{2}=1: 1\right) \delta 7.40(\mathrm{~d}, 2 \mathrm{H}, J=7.5 \mathrm{~Hz}), 7.29(\mathrm{~d}, 2 \mathrm{H}, J=7.5 \mathrm{~Hz}), 7.25(\mathrm{~s}, 1 \mathrm{H}), 6.95(\mathrm{~s}$, $1 \mathrm{H}), 6.82(\mathrm{~s}, 1 \mathrm{H}), 6.75(\mathrm{~s}, 1 \mathrm{H}), 3.66(\mathrm{dd}, 1 \mathrm{H}, J=2.5 \mathrm{~Hz}, 15.0 \mathrm{~Hz}), 3.38(\mathrm{~s}, 3 \mathrm{H}), 2.59(\mathrm{dd}, 1 \mathrm{H}, J=13.5 \mathrm{~Hz}$, $15.0 \mathrm{~Hz}), 2.58(\mathrm{~s}, 3 \mathrm{H}), 2.50(\mathrm{~s}, 3 \mathrm{H}), 2.29(\mathrm{~s}, 3 \mathrm{H}), 1.74(\mathrm{dd}, 1 \mathrm{H}, J=2.5 \mathrm{~Hz}, 13.5 \mathrm{~Hz}), 1.36(\mathrm{~s}, 9 \mathrm{H}), 1.30(\mathrm{~s}$, 9H), 1.17 (s, 9H); vis-NIR $\left(\mathrm{CS}_{2}\right) \lambda_{\max } 879 \mathrm{~nm}$; MALDI-TOF MS m/z $2009\left(M^{-}\right), 1499\left(\mathrm{Lu}_{3} \mathrm{~N} @ \mathrm{I}_{h}-\mathrm{C}_{80}{ }^{-}\right)$.

3c: vis-NIR $\left(\mathrm{CS}_{2}\right) \lambda_{\max } 811 \mathrm{~nm}$; MALDI-TOF MS m/z $2009\left(M^{-}\right), 1499\left(\mathrm{Lu}_{3} \mathrm{~N} @ I_{h}-\mathrm{C}_{80}{ }^{-}\right)$.

\subsection{Photoreaction of $\mathrm{Lu}_{3} N @ I_{h}-\mathrm{C}_{80}$ with 2}

A Pyrex tube $\left(20 \mathrm{~mm}\right.$ i.d.) containing $\mathrm{Lu}_{3} \mathrm{~N} @ I_{h}-\mathrm{C}_{80}\left(1.1 \mathrm{mg}, 7.3 \times 10^{-4} \mathrm{mmol}\right), 2(49.4 \mathrm{mg}$, $\left.1.1 \times 10^{-1} \mathrm{mmol}\right)$, and toluene $(20 \mathrm{~mL})$ was prepared and degassed using freeze-pump-thaw cycles under reduced pressure. These solutions were irradiated for $20 \mathrm{~h}$ under the same conditions. The reaction mixture was separated using preparative HPLC with Buckyprep-M and Buckyprep columns to isolate $4 a, 4 b$, and $4 c$.

4a: ${ }^{1} \mathrm{H}-\mathrm{NMR}\left(\mathrm{CDCl}_{3}: \mathrm{CS}_{2}=1: 1\right) \delta 7.50(\mathrm{t}, 1 \mathrm{H}, J=7.5 \mathrm{~Hz}), 7.47-7.42(\mathrm{~m}, 2 \mathrm{H}), 7.40(\mathrm{~d}, 1 \mathrm{H}, J=7.5 \mathrm{~Hz})$, $7.38-7.34(\mathrm{~m}, 2 \mathrm{H}), 7.23(\mathrm{t}, 1 \mathrm{H}, J=7.5 \mathrm{~Hz}), 7.12(\mathrm{~d}, 1 \mathrm{H}, J=7.5 \mathrm{~Hz}), 7.05(\mathrm{~d}, 1 \mathrm{H}, J=7.5 \mathrm{~Hz}), 6.99$ $(\mathrm{d}, 1 \mathrm{H}, J=7.5 \mathrm{~Hz}), 3.69(\mathrm{dd}, 1 \mathrm{H}, J=2.5 \mathrm{~Hz}, 15.5 \mathrm{~Hz}), 3.51(\mathrm{dq}, 1 \mathrm{H}, J=7.5 \mathrm{~Hz}, 15.0 \mathrm{~Hz}), 3.44(\mathrm{dq}, 1 \mathrm{H}$, $J=7.5 \mathrm{~Hz}, 15.0 \mathrm{~Hz}), 3.14(\mathrm{dq}, 1 \mathrm{H}, J=7.5 \mathrm{~Hz}, 15.0 \mathrm{~Hz}), 3.03(\mathrm{dq}, 1 \mathrm{H}, J=7.5 \mathrm{~Hz}, 15.0 \mathrm{~Hz}), 2.89(\mathrm{dd}, 1 \mathrm{H}$, $J=13.5 \mathrm{~Hz}, 15.5 \mathrm{~Hz}), 2.84(\mathrm{dq}, 1 \mathrm{H}, J=7.5 \mathrm{~Hz}, 15.0 \mathrm{~Hz}), 2.76(\mathrm{dq}, 1 \mathrm{H}, J=7.5 \mathrm{~Hz}, 15.0 \mathrm{~Hz}), 2.53(\mathrm{dq}, 1 \mathrm{H}$, $J=7.5 \mathrm{~Hz}, 15.0 \mathrm{~Hz}), 2.52(\mathrm{dq}, 1 \mathrm{H}, J=7.5 \mathrm{~Hz}, 15.0 \mathrm{~Hz}), 1.84(\mathrm{dd}, 1 \mathrm{H}, J=2.5 \mathrm{~Hz}, 13.5 \mathrm{~Hz}), 1.66(\mathrm{t}, 3 \mathrm{H}$, $J=7.5 \mathrm{~Hz}), 1.34(\mathrm{~s}, 9 \mathrm{H}), 1.22(\mathrm{t}, 3 \mathrm{H}, J=7.5 \mathrm{~Hz}), 0.64(\mathrm{t}, 3 \mathrm{H}, J=7.5 \mathrm{~Hz}), 0.31(\mathrm{t}, 3 \mathrm{H}, J=7.5 \mathrm{~Hz}) ;{ }^{13} \mathrm{C}-\mathrm{NMR}$ $\left(\mathrm{CDCl}_{3}\right) \delta 157.35$ (1C), 156.99 (1C), 156.81 (1C), 155.88 (1C), 155.56 (1C), 155.53 (1C), 154.44 (1C), 154.39 (1C), 153.31 (1C), 153.14 (1C), 151.45 (1C), 151.29 (1C), 150.51 (1C), 149.14 (1C), 148.84 (1C), 148.67 (1C), 148.17 (1C), 147.93 (1C), 147.48 (1C), 147.35 (1C), 147.14 (1C), 146.85 (1C), 146.66 (1C), 146.38 (1C), 144.81 (1C), 144.76 (1C), 144.63 (1C), 144.42 (1C), 144.32 (1C), 144.23 (1C), 143.90 (1C), 142.90 (1C), 142.64 (1C), 142.31 (1C), 142.19 (1C), 142.12 (1C), 141.99 (1C), 141.82 (1C), 141.42 (1C), 140.94 (1C), 140.85 (1C), 140.64 (1C), 140.34 (1C), 139.57 (1C), 139.43 (1C), 139.34 (1C), 138.79 (1C), 138.73 (1C), 138.49 (1C), 138.02 (1C), 137.63 (1C), 137.06 (1C), 137.00 (1C), 136.72 (1C), 136.41 (1C), 136.27 (1C), 136.15 (1C), 136.02 (1C), 135.31 (1C), 135.23 (1C), 135.17 (1C), 135.09 (1C), 135.05 (1C), 134.84 (1C), 134.59 (1C), 134.13 (1C), 131.56 (1C), 130.99 (1C), 130.64 (1C), 130.26 (1C), 129.84 (1C), 129.45 (1C), 129.14 (1C), 128.90 (1C), 128.34 (1C), 127.81 (1C), 127.29 (1C), 127.17 (1C), 126.03 (1C), $125.34(1 \mathrm{C}), 124.90(2 \mathrm{C})$, 118.00 (1C), 110.10 (1C), 109.34 (1C), 103.64 (1C), 63.34 (1C), 58.45 (1C), 55.24 (1C), 34.68 (1C), 34.15 (1C), 33.56 (1C), 31.55 (1C), 30.27 (1C), 29.53 (1C), 21.62 (1C), 15.19 (1C), 15.09 (1C), 15.01 (1C), 14.83 (1C); vis-NIR $\left(\mathrm{CS}_{2}\right) \lambda_{\max } 879 \mathrm{~nm}$; MALDI-TOF MS m/z $1952\left(M^{-}\right), 1499\left(\mathrm{Lu}_{3} \mathrm{~N} @ \mathrm{I}_{\mathrm{h}}-\mathrm{C}_{80}{ }^{-}\right)$.

4b: ${ }^{1} \mathrm{H}-\mathrm{NMR}\left(\mathrm{CDCl}_{3}: \mathrm{CS}_{2}=1: 1\right) \delta 7.32(\mathrm{~d}, 2 \mathrm{H}, J=8.0 \mathrm{~Hz}), 7.37(\mathrm{~d}, 2 \mathrm{H}, J=4.5 \mathrm{~Hz}), 7.31(\mathrm{~d}, 2 \mathrm{H}, J=8.0 \mathrm{~Hz})$, $7.10(\mathrm{t}, 1 \mathrm{H}, J=7.5 \mathrm{~Hz}), 7.02(\mathrm{t}, 1 \mathrm{H}, J=4.5 \mathrm{~Hz}), 6.92(\mathrm{~d}, 1 \mathrm{H}, J=7.5 \mathrm{~Hz}), 6.86(\mathrm{~d}, 1 \mathrm{H}, J=7.5 \mathrm{~Hz}), 3.79(\mathrm{dd}, 1 \mathrm{H}$, $J=2.5 \mathrm{~Hz}, 15.5 \mathrm{~Hz}), 3.74(\mathrm{q}, 2 \mathrm{H}, J=7.5 \mathrm{~Hz}), 3.29(\mathrm{dq}, 1 \mathrm{H}, J=7.5 \mathrm{~Hz}, 15.0 \mathrm{~Hz}), 3.02(\mathrm{dq}, 1 \mathrm{H}, J=7.5 \mathrm{~Hz}$, $15.0 \mathrm{~Hz}), 2.99(\mathrm{dq}, 1 \mathrm{H}, J=7.5 \mathrm{~Hz}, 15.0 \mathrm{~Hz}), 2.84(\mathrm{dq}, 1 \mathrm{H}, J=7.5 \mathrm{~Hz}, 15.0 \mathrm{~Hz}), 2.72(\mathrm{dq}, 1 \mathrm{H}, J=7.5 \mathrm{~Hz}$, $15.0 \mathrm{~Hz}), 2.69(\mathrm{dq}, 1 \mathrm{H}, J=7.5 \mathrm{~Hz}, 15.0 \mathrm{~Hz}), 2.64(\mathrm{dd}, 1 \mathrm{H}, J=13.5 \mathrm{~Hz}, 15.5 \mathrm{~Hz}), 1.84(\mathrm{t}, 3 \mathrm{H}, J=7.5 \mathrm{~Hz})$, 
$1.75(\mathrm{dd}, 1 \mathrm{H}, J=2.5 \mathrm{~Hz}, 13.5 \mathrm{~Hz}), 1.26(\mathrm{~s}, 9 \mathrm{H}), 1.21(\mathrm{t}, 3 \mathrm{H}, J=7.5 \mathrm{~Hz}), 0.56(\mathrm{t}, 3 \mathrm{H}, J=7.5 \mathrm{~Hz}), 0.55(\mathrm{t}, 3 \mathrm{H}$, $J=7.5 \mathrm{~Hz})$; vis-NIR $\left(\mathrm{CS}_{2}\right) \lambda_{\max } 882 \mathrm{~nm}$; MALDI-TOF MS m/z $1952\left(M^{-}\right), 1499\left(\mathrm{Lu}_{3} \mathrm{~N}_{\mathrm{I}_{h}}-\mathrm{C}_{80}{ }^{-}\right)$.

4c: vis-NIR $\left(\mathrm{CS}_{2}\right) \lambda_{\max } 803 \mathrm{~nm}$; MALDI-TOF MS m/z $1952\left(M^{-}\right), 1499\left(\mathrm{Lu}_{3} \mathrm{~N} @ I_{h}{ }^{-} \mathrm{C}_{80}{ }^{-}\right)$.

\subsection{Computational Method}

All calculations were conducted using the Gaussian09 [29] program. The optimized geometries were calculated at the B3LYP [26-28] level of theory using basis sets of 6-31G(d) [30] for C, H, N, Si atoms, and SDD [31] for $\mathrm{Lu}$ atoms.

\section{Conclusions}

In summary, the photochemical addition of siliranes 1 and 2 to $\mathrm{Lu}_{3} \mathrm{~N} @ I_{h}-\mathrm{C}_{80}$ afforded the corresponding [5,6]- and [6,6]-adducts. The [5,6]-adducts $\mathbf{3 a}, \mathbf{3} \mathbf{b}, \mathbf{4} \mathbf{a}$, and $\mathbf{4} \mathbf{b}$ were characterized on the basis of spectroscopic and electrochemical studies and theoretical calculations. The electron-donating effect of carbosilylation on $\mathrm{Lu}_{3} \mathrm{~N} @ I_{h}-\mathrm{C}_{80}$ was confirmed by the redox properties of $\mathbf{3} \mathbf{a}, \mathbf{3} \mathbf{b}, \mathbf{4} \mathbf{a}$, and $4 \mathbf{b}$, which showed remarkably low first oxidation potentials. The carbosilylation also resulted in cathodic shifts of the first reduction potentials compared to those of the [5,6]-pyrrolidino adducts. Such functional groups with various electronic effects will contribute to the utilization of EMFs for future applications. Further studies of novel functionalizing methods based on organosilanes are now underway.

Supplementary Materials: Supplementary materials are available online.

Acknowledgments: This work was supported by a Grant-in-Aid for Scientific Research on Innovative Areas (No. 20108001, "pi-Space"), a Grant-in-Aid for Scientific Research (A) (No. 202455006), (B) (No. 24350019) and (C) (No. 17K05797), and Specially Promoted Research (no. 22000009) from the Ministry of Education, Culture, Sports, Science, and Technology of Japan.

Author Contributions: M.K. conceived and designed the experiments; K.M., T.K., S.F., and Y.A. performed the experiments; M.Y. and Y.M. contributed to the analysis of the products; Q.L. and S.N. performed computational studies; M.K. and T.A. wrote the paper.

Conflicts of Interest: The authors declare no conflict of interest.

\section{References}

1. Akasaka, T.; Nagase, S. (Eds.) Endofullerenes: A New Family of Carbon Clusters; Kluwer: Dordrecht, The Netherlands, 2002.

2. Dunsch, L.; Yang, S. Metal nitride cluster fullerenes: Their current state and future prospects. Small 2007, 8, 1298-1320. [CrossRef] [PubMed]

3. Chaur, M.N.; Melin, F.; Ortiz, A.L.; Echegoyen, L. Chemical, electrochemical, and structural properties of endohedral metallofullerenes. Angew. Chem. Int. Ed. 2009, 48, 7514-7538. [CrossRef] [PubMed]

4. Yamada, M.; Akasaka, T.; Nagase, S. Endohedral metal atoms in pristine and functionalized fullerene cages. Acc. Chem. Res. 2010, 43, 92-102. [CrossRef] [PubMed]

5. Akasaka, T.; Wudl, F.; Nagase, S. (Eds.) Chemistry of Nanocarbons; Wiley: Chichester, UK, 2010.

6. Lu, X.; Feng, L.; Akasaka, T.; Nagase, S. Current status and future developments of endohedral metallofullerenes. Chem. Soc. Rev. 2012, 41, 7723-7760. [CrossRef] [PubMed]

7. Rivera-Nazario, D.M.; Pinzón, J.R.; Stevenson, S.; Echegoyen, L.A. Buckyball maracas: Exploring the inside and outside properties of endohedral fullerenes. J. Phys. Org. Chem. 2013, 26, 194-205. [CrossRef]

8. Yamada, M.; Akasaka, T.; Nagase, S. Carbene additions to fullerenes. Chem. Rev. 2013, 113, 7209-7264. [CrossRef] [PubMed]

9. Lu, X.; Akasaka, T.; Nagase, S. Carbide cluster metallofullerenes: Structure, properties, and possible origin. Acc. Chem. Res. 2013, 46, 1627-1635. [CrossRef] [PubMed]

10. Popov, A.A.; Yang, S.; Dunsch, L. Endohedral fullerenes. Chem. Rev. 2013, 113, 5989-6113. [CrossRef] [PubMed] 
11. Nagase, S. Theory and calculations of molecules containing heavier main group elements and fullerenes encaging transition metals: Interplay with experiment. Bull. Chem. Soc. Jpn. 2014, 87, 167-195. [CrossRef]

12. Yamada, M.; Akasaka, T. Emergence of highly elaborated $\pi$-space and extending its functionality based on nanocarbons: New vistas in the fullerene world. Bull. Chem. Soc. Jpn. 2014, 87, 1289-1314. [CrossRef]

13. Stevenson, S.; Rice, G.; Glass, T.; Harich, K.; Cromer, F.; Jordan, M.R.; Craft, J.; Bible, R.; Olmstead, M.M.; Maitra., K.; et al. Small-bandgap endohedral metallofullerenes in high yield and purity. Nature 1999, 401, 55-57.

14. Zhang, J.; Stevenson, S.; Dorn, H.C. Trimetallic nitride template endohedral metallofullerenes: Discovery, structural characterization, reactivity, and applications. Acc. Chem. Res. 2013, 46, 1458-1557. [CrossRef] [PubMed]

15. Ross, R.B.; Cardona, C.M.; Guldi, D.M.; Sankaranarayanan, S.G.; Reese, M.O.; Kopidakis, N.; Peet, J.; Walker, B.; Bazan, G.C.; Van Keuren, E.; et al. Endohedral fullerenes for organic photovoltaic devices. Nat. Mater. 2009, 8, 208-212. [CrossRef] [PubMed]

16. Ross, R.B.; Cardona, C.M.; Swain, F.B.; Guldi, D.M.; Sankaranarayanan, S.G.; Van Keuren, E.; Holloway, B.C.; Drees, M. Tuning conversion efficiency in metallo endohedral fullerene-based organic photovoltaic devices. Adv. Funct. Mater. 2009, 19, 2332-2337. [CrossRef]

17. Liedtke, M.; Sperlich, A.; Kraus, H.; Baumann, A.; Deibel, C.; Wirix, M.J.; Loos, J.; Cardona, C.M.; Dyakonov, V. Triplet exciton generation in bulk-heterojunction solar cells based on endohedral fullerenes. J. Am. Chem. Soc. 2011, 133, 9088-9094. [CrossRef] [PubMed]

18. Sato, K.; Kako, M.; Suzuki, M.; Mizorogi, N.; Tsuchiya, T.; Olmstead, M.M.; Balch, A.L.; Akasaka, T.; Nagase, S. Synthesis of silylene-bridged endohedral metallofullerene $\mathrm{Lu}_{3} \mathrm{~N} @ I_{h}-\mathrm{C}_{80}$. J. Am. Chem. Soc. 2012, 134, 16033-16039. [CrossRef] [PubMed]

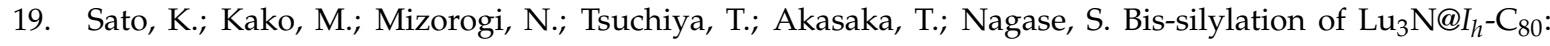
Considerable variation in the electronic structures. Org. Lett. 2012, 14, 5908-5911. [CrossRef] [PubMed]

20. Kako, M.; Miyabe, M.; Sato, K.; Suzuki, M.; Mizorogi, N.; Wang, W.-W.; Yamada, M.; Maeda, Y.; Olmstead, M.M.; Balch, A.L.; et al. Preparation, structural determination, and characterization of electronic properties of bis-silylated and bis-germylated $\mathrm{Lu}_{3} \mathrm{~N} @ I_{h}-\mathrm{C}_{80}$. Chem. Eur. J. 2015, 21, 16411-16420. [CrossRef] [PubMed]

21. Kako, M.; Sugiura, T.; Akasaka, T. Photochemical addition of silirane to endohedral metallofullerene: Electronic properties of carbosilylated $\mathrm{Sc}_{3} \mathrm{~N} @ I_{h}-\mathrm{C}_{80}$. Phosphorus Sulfur Silicon Relat. Elem. 2016, 191, 201-206. [CrossRef]

22. Nagatsuka, J.; Sugitani, S.; Kako, M.; Nakahodo, T.; Mizorogi, N.; Ishitsuka, M.O.; Maeda, Y.; Tsuchiya, T.; Akasaka, T.; Gao, X.; et al. Photochemical addition of $\mathrm{C}_{60}$ with siliranes: Synthesis and characterization of carbosilylated and hydrosilylated $\mathrm{C}_{60}$ derivatives. J. Am. Chem. Soc. 2010, 132, 12106-12120. [CrossRef] [PubMed]

23. Chen, N.; Pinzón, J.R.; Echegoyen, L. Influence of the encapsulated clusters on the electrochemical behaviour of endohedral fullerene derivatives: Comparative study of $\mathrm{N}$-tritylpyrrolidino derivatives of $\mathrm{Sc}_{3} \mathrm{~N} @ \mathrm{I}_{h}-\mathrm{C}_{80}$ and $\mathrm{Lu}_{3} \mathrm{~N} @ \mathrm{I}_{h}-\mathrm{C}_{80}$. ChemPhysChem 2011, 12, 1422-1425. [CrossRef] [PubMed]

24. Aroua, S.; Yamakoshi, Y. Prato reaction of $\mathrm{M}_{3} \mathrm{~N} @ \mathrm{I}_{h}-\mathrm{C}_{80}(\mathrm{M}=\mathrm{Sc}, \mathrm{Lu}, \mathrm{Y}, \mathrm{Gd})$ with reversible isomerization. J. Am. Chem. Soc. 2012, 134, 20242-20245. [CrossRef] [PubMed]

25. Aroua, S.; Garcia-Borras, M.; Osuna, S.; Yamakoshi, Y. Rearrangement of $\mathrm{M}_{3} \mathrm{~N} @ \mathrm{I}_{h}-\mathrm{C}_{80}$ fulleropyrrolidines: Exohedral functional groups versus endohedral metal clusters. Chem. Eur. J. 2014, 20, 14032-14039. [CrossRef] [PubMed]

26. Becke, A.D. Density-functional exchange-energy approximation with correct asymptotic behavior. Phys. Rev. A 1988, 38, 3098-3100. [CrossRef]

27. Becke, A.D. Densityfunctional thermochemistry. III. The role of exact exchange. J. Chem. Phys. 1993, 98, 5648-5652. [CrossRef]

28. Lee, C.; Yang, W.; Parr, R.G. Development of the Colle-Salvetti correlation-energy formula into a functional of the electron density. Phys. Rev. B 1988, 37, 785-789. [CrossRef]

29. Frisch, M.J.; Trucks, G.W.; Schlegel, H.B.; Scuseria, G.E.; Robb, M.A.; Cheeseman, J.R.; Scalmani, G.; Barone, V.; Mennucci, B.; Petersson, G.A.; et al. Gaussian 09, Revision D.01, Gaussian, Inc.: Wallingford, CT, USA, 2013. 
30. Hehre, W.J.; Ditchfield, R.; Pople, J.A. Self-consistent molecular orbital methods. XII. Further extensions of Gaussian-type basis sets for use in molecular orbital studies of organic molecules. J. Chem. Phys. 1972, 56, 2257-2261. [CrossRef]

31. Cao, X.Y.; Dolg, M. Segmented contraction scheme for small-core lanthanide pseudopotential basis sets. J. Mol. Struct. 2002, 581, 139-147. [CrossRef]

Sample Availability: Not available.

(C) 2017 by the authors. Licensee MDPI, Basel, Switzerland. This article is an open access article distributed under the terms and conditions of the Creative Commons Attribution (CC BY) license (http:// creativecommons.org/licenses/by/4.0/). 